\title{
Anethole reduces oxidative stress and improves in vitro survival and activation of primordial follicles
}

\author{
N.A.R. Sá ${ }^{1}$, J.B. Bruno ${ }^{1}$, D.D. Guerreiro ${ }^{1}$, J. Cadenas ${ }^{1}$, B.G. Alves ${ }^{2}$, F.W.S. Cibin $^{3}$, \\ J.H. Leal-Cardoso ${ }^{4}$, E.L. Gastal ${ }^{5}$ and J.R. Figueiredo ${ }^{1}$
}

${ }^{1}$ Laboratório de Manipulação de Oócitos e Folículos Pré-antrais (LAMOFOPA), Faculdade de Medicina Veterinária, Universidade Estadual do Ceará, Fortaleza, CE, Brasil ${ }^{2}$ Laboratório de Biologia da Reprodução, Instituto de Ciências Biomédicas, Universidade Federal de Uberlândia, Uberlândia, MG, Brasil ${ }^{3}$ Laboratório de Biotecnologia da Reprodução (Biotech), Campus Uruguaiana, Universidade Federal do Pampa, Uruguaiana, RS, Brasil ${ }^{4}$ Laboratório de Eletrofisiologia (LEF), Instituto Superior de Ciências Biomédicas, Universidade Estadual do Ceará, Fortaleza, CE, Brasil ${ }^{5}$ Department of Animal Science, Food and Nutrition, Southern Illinois University, Carbondale, Illinois, USA

\begin{abstract}
Primordial follicles, the main source of oocytes in the ovary, are essential for the maintenance of fertility throughout the reproductive lifespan. To the best of our knowledge, there are no reports describing the effect of anethole on this important ovarian follicle population. The aim of the study was to investigate the effect of different anethole concentrations on the in vitro culture of caprine preantral follicles enclosed in ovarian tissue. Randomized ovarian fragments were fixed immediately (non-cultured treatment) or distributed into five treatments: $\alpha-\mathrm{MEM}^{+}$(cultured control), $\alpha-\mathrm{MEM}^{+}$supplemented with ascorbic acid at $50 \mu \mathrm{g} / \mathrm{mL}$ (AA), and anethole at 30 (AN30), 300 (AN300), or $2000 \mu \mathrm{g} / \mathrm{mL}$ (AN2000), for 1 or 7 days. After 7 days of culture, a significantly higher percentage of morphologically normal follicles was observed when anethole at $2000 \mu \mathrm{g} / \mathrm{mL}$ was used. For both culture times, a greater percentage of growing follicles was observed with the AN30 treatment compared to AA and AN2000 treatments. Anethole at 30 and $2000 \mu \mathrm{g} / \mathrm{mL}$ concentrations at days 1 and 7 of culture resulted in significantly larger follicular diameter than in the cultured control treatment. Anethole at $30 \mu \mathrm{g} / \mathrm{mL}$ concentration at day 7 showed significantly greater oocyte diameter than the other treatments, except when compared to the AN2000 treatment. At day 7 of culture, levels of reactive oxygen species (ROS) were significantly lower in the AN30 treatment than the other treatments. In conclusion, supplementation of culture medium with anethole improves survival and early follicle development at different concentrations in the caprine species.
\end{abstract}

Key words: Antioxidant; Anethole; ROS; Primordial follicle; Caprine

\section{Introduction}

Primordial follicles are essential for the maintenance of fertility throughout the reproductive lives of mammalian females (1). Notwithstanding, the vast majority of this follicular category is lost due to the natural process named atresia. In order to recover and use these follicles, preantral follicle culture is an important tool to study in vitro folliculogenesis, including the effect of different substances (2).

Studies demonstrated that follicles cultured in vitro have lower developmental capability than those grown in vivo (3). Under in vitro conditions, follicles may be exposed to supra-physiological oxygen concentration (20\%) (4). This may ultimately increase the production of reactive oxygen species (ROS), promoting oxidative stress (5).

Several studies have shown that high ROS levels produced during in vitro culture impair follicle development by damaging their cellular and molecular structures (for review, see Agarwal et al. (6). In this regard, a great variety of antioxidants such as selenium (7), $\alpha$-tocopherol (8), ascorbic acid $(5,9)$, and more recently, anethole (10) have been added to the culture media to reduce ROS production.

Anethole, the major constituent of the essential oil extracted from Croton zehntneri Pax \& K.Hoffm (Euphorbiaceae), has been used in folk medicine as well as in the food and cosmetic industries $(11,12)$. Hence, this compound may act as an anti-inflammatory (13), anesthetic (14), anticarcinogen (15), and antioxidant $(10,13,15)$. Recently, anethole has been shown to improve the number of meiotically competent oocytes when added during in vitro culture of isolated caprine secondary follicles (10). Nevertheless, to the best of our knowledge, there are no reports describing the effect of anethole on in vitro culture of early stage preantral follicles (i.e., primordial, transition, and primary). The originality of the present study is based on the fact that follicular requirements vary according to the 
stage of follicle development. It has been shown recently that the transcriptional profiles of caprine secondary and early antral follicles differ in 2466 genes (16). Furthermore, Cadenas et al. (17) reported that caprine preantral and early antral follicles behave differently under the same culture conditions.

The objective of the present study was to evaluate the effect of different anethole concentrations on caprine in vitro early folliculogenesis. For this purpose, the following end points were evaluated: i) survival, ii) activation, iii) follicle and oocyte diameters, iv) cell proliferation, and v) ROS production of caprine early preantral follicles cultured in vitro enclosed in the ovarian tissue. In this study, caprine ovaries were used once the goat model had been reported to be appropriate for studying the effects of factors on in vitro folliculogenesis, with potential translational aspects for assisted reproductive techniques in human. Several similarities do exist between human and goat ovaries, such as size, organ texture, preantral follicle diameter, and folliculogenesis length (18).

\section{Material and Methods}

\section{Chemicals and media}

Unless otherwise mentioned, the culture media, ascorbic acid, anethole, and other chemicals used in the present experiment were purchased from Sigma-Aldrich (USA).

\section{Source of ovaries}

All procedures and the research protocol (\#1698730) were approved by the Ethics and Animal Use Committee (CEUA) of Universidade Estadual do Ceará (UECE), Brazil. Ovaries $(n=10)$ from five adult crossbred goats (1-3 years old) were collected at a local slaughterhouse. The surrounding fat tissue and ligaments were removed and the ovaries were washed in $70 \%$ alcohol, followed by two washes in minimum essential medium (MEM) plus HEPES (MEM-HEPES). The ovaries were placed into tubes containing $15 \mathrm{~mL}$ of MEM-HEPES, supplemented with penicillin $(100 \mu \mathrm{g} / \mathrm{mL})$ and streptomycin $(100 \mu \mathrm{g} / \mathrm{mL})$ and then transported to the laboratory at $4^{\circ} \mathrm{C}$ within $1 \mathrm{~h}(19)$.

\section{Culture medium}

The basic medium used was $\alpha-\mathrm{MEM}^{+}$(M5650, $\mathrm{pH} 7.2$ 7.4) supplemented with $1.25 \mathrm{mg} / \mathrm{mL}$ bovine serum albumin (BSA), ITS (10 $\mu \mathrm{g} / \mathrm{mL}$ insulin, $5.5 \mu \mathrm{g} / \mathrm{mL}$ transferrin, $5 \mathrm{ng} / \mathrm{mL}$ selenium), $2 \mathrm{mM}$ glutamine, and $2 \mathrm{mM}$ hypoxanthine, which was also named $\alpha-\mathrm{MEM}^{+}$. Incubation was carried out at $39^{\circ} \mathrm{C}$ in $5 \% \mathrm{CO}_{2}$ in air for 1 or 7 days. Fresh media were prepared immediately before use and incubated for $1 \mathrm{~h}$ prior to use, with $1 \mathrm{~mL}$ in each well. The remaining fragments were individually cultured in a 24-well plate containing $1 \mathrm{~mL} \alpha-\mathrm{MEM}^{+}$culture medium. The culture medium was replaced with fresh medium every 2 days. Each treatment was replicated five times.

\section{Experimental design}

In the laboratory, the ovarian cortex of each pair $(n=5)$ was removed with a sterile scalpel and divided into 22 fragments $(3 \times 3 \times 1 \mathrm{~mm})$. Two fragments were randomly taken and immediately fixed for the non-cultured control treatment as described below. The remaining fragments were randomly distributed (two fragments per treatment) into the five treatments as follows: $\alpha-\mathrm{MEM}^{+}$(cultured control), $\alpha-\mathrm{MEM}^{+}$supplemented with ascorbic acid at $50 \mu \mathrm{g} / \mathrm{mL}$ (AA), and anethole at 30 (AN30), 300 (AN300), or $2000 \mu \mathrm{g} / \mathrm{mL}$ (AN2000). The concentration of ascorbic acid (20), and anethole (30, 300, and $2000 \mu \mathrm{g} / \mathrm{mL})$ were chosen based on previous studies $(10,21)$.

\section{Evaluation of follicular morphology}

Fresh, cultured control and treated cultured ovarian fragments were fixed in buffered $4 \%$ paraformaldehyde in phosphate buffered saline (PBS) for $12 \mathrm{~h}$ at $4^{\circ} \mathrm{C}$, dehydrated in a graded series of ethanol, clarified with xylene, embedded in paraffin wax, and serially sectioned into $7 \mu \mathrm{m}$ thickness. The sections were stained with periodic acid Schiff (PAS) and hematoxylin. For morphological evaluation, anonymous coded slides were examined on a microscope (Nikon, Japan) under $400 \times$ magnification, and the follicles were classified according to integrity and developmental stage.

The developmental stages of follicles have been defined previously (2) as: i) primordial (one layer of flattened granulosa cells around the oocyte); ii) transitional (one layer of flattened to cuboidal granulosa cells around the oocyte); iii) primary (a single layer of cuboidal granulosa cells); iv) secondary (two or more layers of cuboidal granulosa cells). The percentage of primordial and developing follicles was calculated on day 0 (control) and after 1 or 7 days of culture in each treatment. In addition, follicular and oocyte diameter were evaluated using only normal follicles on days 0,1 , and 7 of culture. Only follicles with a visible oocyte nucleus were evaluated to avoid counting the same follicle twice. Furthermore, follicles were classified as either morphologically normal (follicles containing an intact oocyte and granulosa cells well organized in layers without pyknotic nucleus) or degenerated (oocyte with a pycnotic nucleus, retracted cytoplasm, or disorganized granulosa cells detached from the basement membrane) (22).

\section{Immunohistochemical evaluation}

Ovarian tissue derived from the non-cultured control treatment, as well as from the cultured control, AA, AN30, AN300, and AN2000 treatments were evaluated by proliferating cell nuclear antigen (PCNA). The blockage for endogenous peroxidase activity, endogenous biotin, and nonspecific binding was performed by incubation in $5 \%$ normal goat serum and 3\% triton $\times 1000$ diluted in PBS. After epitopes activation, slides were incubated overnight at $4^{\circ} \mathrm{C}$ with antiPCNA (1:300, AB2426, ABCAN, Inc., USA). 



Figure 1. Distribution of PCNA immunoreactivity. $A$, absent, $B$, weak $(<50 \%)$, or $C$, strong $(>50 \%)$ in cells in the ovary by immunohistochemistry method. Bars $=50 \mu \mathrm{m}$.

Thereafter, the slides were washed in PBS and incubated with biotinylated anti-rabbit immunoglobulin $\mathrm{G}(\mathrm{lgG})$ secondary antibody (1:500, AB97049, ABCAN, Inc., USA). After that, the slides were washed, and the location of the protein was developed with diaminobenzidine (DAB; 1 drop of DAB for $1 \mathrm{~mL}$ of substratum, K346811-2; Dako, Inc., USA). Finally, the sections were counterstained with hematoxylin. The negative controls were carried out by replacing the primary antibody. Once mounted, the slides were visualized under a light microscope. In all treatments, primordial and developing follicles were evaluated. Follicles with at least one granulosa cell stained for PCNA were considered as positively stained. The scores attributed to the immunostaining ranged from weak to strong, according to the signal intensity indicated by the brown staining (Figure 1). The immunostaining was classified as absent (Figure 1A), weak $(<50 \%$, Figure $1 \mathrm{~B})$, or strong $(>50 \%$, Figure $1 \mathrm{C})(23)$.

\section{Reactive oxygen species (ROS) levels}

Levels of ROS were determined by a spectrofluorimetric method (24), using $2^{\prime}, 7^{\prime}$-dihydrodichlorofluorescein diacetate (DCHF-DA) assay. Sample aliquot $(50 \mu \mathrm{L})$ was incubated at room temperature with $10 \mu \mathrm{L}$ of DCHF-DA $(1 \mathrm{mM})$. The oxidation of DCHF-DA to fluorescent dichlorofluorescein (DCF) was measured for the detection of intracellular ROS. The DCF fluorescence intensity emission was recorded at $520 \mathrm{~nm}$ (with $480 \mathrm{~nm}$ excitation) $2 \mathrm{~h}$ after the addition of DCHF-DA to the medium.

\section{Statistical analyses}

Statistical analyses were carried out using Sigma Plot 11 (Systat Software Inc., USA). The percentage of morphologically normal follicles, follicular activation, and cell proliferation among treatments and days of culture were analyzed by the chi-squared test. Data without normally distribution (Shapiro-Wilk test) was transformed in base 10 logarithm. Comparisons of means (ROS, follicular, and oocyte diameters) were performed by Kruskal-Wallis (among treatments) and Mann-Whitney (between days of culture) tests. Data are reported as percentage and as means \pm SEM. Differences were considered to be significant when $\mathrm{P}<0.05$.

\section{Results}

\section{Follicle survival before and after culture}

A total of 4,589 preantral follicles were analyzed by classical histology. Normal (Figure $2 \mathrm{~A}$ ) and degenerated (Figure 2B and C) follicles after 7 days of culture in $30 \mu \mathrm{g} / \mathrm{mL}$ anethole treatment are shown.

The percentage of morphologically normal preantral follicles in the non-cultured control treatment and after 1 or 7 days of in vitro culture in all treatments is shown in Table 1. In all treatments, the percentage of normal follicles was lower $(P<0.05)$ than in the non-cultured control treatment, and was reduced $(P<0.05)$ from day 1 to day 7 of culture. At day 1 of culture, anethole at 30 and $300 \mu \mathrm{g} / \mathrm{mL}$ reduced $(P<0.05)$ the percentage of normal follicles when compared to the cultured control treatment. However, when anethole at $2000 \mu \mathrm{g} / \mathrm{mL}$ was used, the greatest $(P<0.05)$ percentage of normal follicles on day 7 was obtained.

\section{Activation of primordial follicles after culture}

The percentage of activation of preantral follicles in non-cultured control treatment and after 1 or 7 days of culture is shown in Table 2. As early as day 1 of culture, a reduction $(P<0.05)$ in the percentage of primordial follicles with a concomitant increase $(P<0.05)$ in the percentage of growing follicles was observed in all treatments compared to the non-cultured control treatment. In addition, in all treatments, the percentage of growing follicles increased $(P<0.05)$ throughout the culture period. At day 1 of culture, $A A$ and anethole supplementation increased $(P<0.05)$ the percentage of growing follicles compared to the cultured control treatment. For both culture times, a higher $(P<0.05)$ percentage of growing follicles was observed in the AN30 treatment compared to AA and AN2000 treatments. 

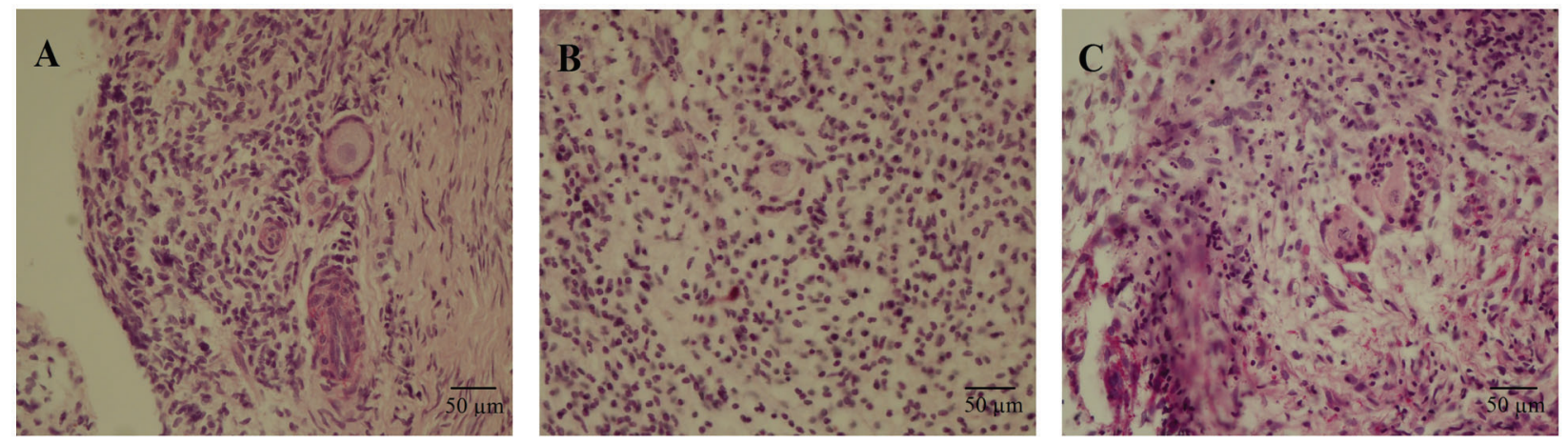

Figure 2. Morphologic aspects of preantral follicles after 7 days of culture in $30 \mu \mathrm{g} / \mathrm{mL}$ anethole treatment. $A$, normal follicle, $B$ and $C$, abnormal follicles. Bars $=50 \mu \mathrm{m}$.

Table 1. Percentage of morphologically normal preantral follicles in non-cultured ovarian tissue and in tissue cultured for 1 or 7 days in control medium with or without supplementation of $50 \mu \mathrm{g} / \mathrm{mL}$ of ascorbic acid (AA) or anethole 30 (AN30), 300 (AN300) or $2000 \mu \mathrm{g} / \mathrm{mL}$ (AN2000).

\begin{tabular}{|c|c|c|c|}
\hline \multirow[t]{2}{*}{ Treatments } & \multicolumn{3}{|c|}{ Normal preantral follicles (\%) } \\
\hline & Day 0 & Day 1 & Day 7 \\
\hline Non-cultured control & $92.3(430 / 466)$ & & \\
\hline Cultured control & & $62.5(364 / 582)^{\star \mathrm{aA}}$ & $36.3(149 / 410)^{\star \mathrm{bA}}$ \\
\hline AA & & $60.2(283 / 470)^{\star a A B}$ & $36.6(167 / 456)^{\star \mathrm{bA}}$ \\
\hline AN30 & & $55.3(273 / 494)^{\star \mathrm{aBC}}$ & $37.8(84 / 222)^{\star \mathrm{bA}}$ \\
\hline AN300 & & $52.2(216 / 414)^{\star \mathrm{aC}}$ & $34.7(87 / 251)^{\star \mathrm{bA}}$ \\
\hline AN2000 & & $59.1(319 / 540)^{\star a A B}$ & $51.9(181 / 349)^{\star \mathrm{bB}}$ \\
\hline
\end{tabular}

${ }^{*} \mathrm{P}<0.05$ compared to non-cultured control group. ${ }^{a, b}$ Within days in the same treatment; ${ }^{A, B, C}$ Within treatments in the same period. Different superscript letters indicate significant difference (chi-squared test).

Table 2. Percentage of primordial and growing follicles in non-cultured ovarian tissue and tissue cultured for 1 or 7 days in control medium with or without supplementation of $50 \mu \mathrm{g} / \mathrm{mL}$ of ascorbic acid (AA) or anethole at 30 (AN30), 300 (AN300) or $2000 \mu \mathrm{g} / \mathrm{mL}$ (AN2000).

\begin{tabular}{|c|c|c|c|c|c|c|}
\hline \multirow[t]{2}{*}{ Treatments } & \multicolumn{3}{|c|}{ Primordial follicles (\%) } & \multicolumn{3}{|c|}{ Growing follicles (\%) } \\
\hline & Day 0 & Day 1 & Day 7 & Day 0 & Day 1 & Day 7 \\
\hline Non-cultured control & $58.8(253 / 430)$ & & & $41.16(177 / 430)$ & & \\
\hline Cultured control & & $43.1(157 / 364)^{\star \mathrm{aA}}$ & $6.0(9 / 149)^{\star \mathrm{bAB}}$ & & $56.9(207 / 364)^{\star \mathrm{AA}}$ & $94.0(140 / 149)^{\star \mathrm{bAB}}$ \\
\hline AA & & $31.8(90 / 283)^{\star \mathrm{aB}}$ & $8.4(14 / 167)^{\star \mathrm{bA}}$ & & $68.2(193 / 283)^{\star a B}$ & $91.6(153 / 167)^{\star \mathrm{bA}}$ \\
\hline AN30 & & $24.2(66 / 273)^{\star \mathrm{aC}}$ & $1.2(1 / 84)^{\star \mathrm{bB}}$ & & $75.8(207 / 273)^{\star \mathrm{aC}}$ & $98.8(83 / 84)^{\star \mathrm{bB}}$ \\
\hline AN300 & & $26.4(57 / 216)^{\star \mathrm{aBC}}$ & $2.3(2 / 87)^{\text {*bB }}$ & & $73.6(159 / 216)^{\star a B C}$ & $97.7(85 / 87)^{\star \mathrm{bB}}$ \\
\hline AN2000 & & $32.3(103 / 319)^{\star \mathrm{aB}}$ & $8.8(16 / 181)^{\star \mathrm{bA}}$ & & $67.7(216 / 319)^{\star \mathrm{aB}}$ & $91.2(165 / 181)^{\star \mathrm{bA}}$ \\
\hline
\end{tabular}

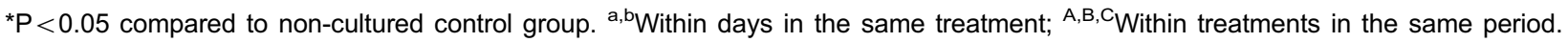
Different superscript letters indicate significant difference (chi-squared test).

\section{In vitro growth of preantral follicles}

The follicular and oocyte diameters in the non-cultured control treatment and after 1 or 7 days of culture are shown in Table 3. Only anethole at 30 and $2000 \mu \mathrm{g} / \mathrm{mL}$ concentrations showed greater $(P<0.05)$ follicular (days 1 and 7$)$ and oocyte (day 7 ) diameters when compared to non-cultured control treatment. Anethole at 30 and $2000 \mu \mathrm{g} / \mathrm{mL}$ concentrations at days 1 and 7 of culture resulted in larger $(\mathrm{P}<$ $0.05)$ follicular diameter than in the cultured control treatment; furthermore, both concentrations yielded larger $(\mathrm{P}<$ 0.05) follicular diameter at day 7 compared to AA treatment. Anethole at $30 \mu \mathrm{g} / \mathrm{mL}$ concentration at day 7 showed 
Table 3. Follicle and oocyte diameters in non-cultured ovarian tissue and tissue cultured for 1 or 7 days in control medium with or without supplementation of $50 \mu \mathrm{g} / \mathrm{mL}$ of ascorbic acid (AA) or anethole at 30 (AN30), 300 (AN300) or $2000 \mu \mathrm{g} / \mathrm{mL}$ (AN2000).

\begin{tabular}{|c|c|c|c|c|c|c|}
\hline \multirow[t]{2}{*}{ Treatments } & \multicolumn{3}{|c|}{ Follicles $(\mu \mathrm{m})$} & \multicolumn{3}{|c|}{ Oocyte $(\mu \mathrm{m})$} \\
\hline & Day 0 & Day 1 & Day 7 & Day 0 & Day 1 & Day 7 \\
\hline Non-cultured control & $24.6 \pm 0.5$ & & & $18.8 \pm 0.3$ & & \\
\hline Cultured control & & $23.7 \pm 0.9^{\mathrm{aA}}$ & $24.5 \pm 0.8^{\mathrm{aA}}$ & & $19.6 \pm 0.6^{\mathrm{aAB}}$ & $17.7 \pm 0.7^{\mathrm{aAC}}$ \\
\hline AA & & $25.0 \pm 1.1^{\mathrm{aAB}}$ & $24.8 \pm 0.9^{\mathrm{aA}}$ & & $18.5 \pm 0.6^{\mathrm{aA}}$ & $18.1 \pm 0.7^{\mathrm{aAC}}$ \\
\hline AN30 & & $27.0 \pm 1.0^{\star a B}$ & $28.7 \pm 1.0^{\star a B}$ & & $20.3 \pm 0.7^{\mathrm{aB}}$ & $21.1 \pm 0.8^{\star a B}$ \\
\hline AN300 & & $26.1 \pm 1.1^{\mathrm{aAB}}$ & $24.8 \pm 0.7^{\mathrm{aA}}$ & & $19.1 \pm 0.6^{\mathrm{aAB}}$ & $17.2 \pm 0.4^{\star \mathrm{bC}}$ \\
\hline AN2000 & & $27.8 \pm 1.1^{\star \mathrm{aB}}$ & $27.3 \pm 0.9^{\star a B}$ & & $19.9 \pm 0.7^{\mathrm{aAB}}$ & $19.5 \pm 0.7^{\star A B}$ \\
\hline
\end{tabular}

Data are reported as means $\pm S E$. ${ }^{*} P<0.05$ compared to non-cultured control group. ${ }^{a, b}$ Within days in the same treatment; ${ }^{A, B, C}$ Within treatments in the same period. Different superscript letters indicate significant difference. Kruskal-Wallis (among treatments) and MannWhitney (between days of culture) tests were used.

Table 4. Levels of reactive oxygen species (ROS) measured in the culture medium of ovarian tissue cultured for 1 or 7 days in control medium with or without supplementation of $50 \mu \mathrm{g} / \mathrm{mL}$ of ascorbic acid (AA) or anethole at 30 (AN30), 300 (AN300) or $2000 \mu \mathrm{g} / \mathrm{mL}$ (AN2000).

\begin{tabular}{lcc}
\hline Treatments & \multicolumn{2}{c}{ ROS } \\
\cline { 2 - 3 } & Day 1 & Day 7 \\
\hline Cultured control & $14.3 \pm 2.8^{\mathrm{aA}}$ & $18.9 \pm 1.3^{\mathrm{aA}}$ \\
AA & $11.1 \pm 1.7^{\mathrm{aAC}}$ & $19.2 \pm 1.1^{\mathrm{bA}}$ \\
AN30 & $7.8 \pm 1.1^{\mathrm{aBC}}$ & $11.7 \pm 1.6^{\mathrm{aB}}$ \\
AN300 & $8.5 \pm 1.0^{\mathrm{aAB}}$ & $16.1 \pm 1.3^{\mathrm{bA}}$ \\
AN2000 & $7.1 \pm 0.9^{\mathrm{aB}}$ & $20.8 \pm 2.9^{\mathrm{bA}}$ \\
\hline
\end{tabular}

Data are reported as means $\pm \mathrm{SE}$. ${ }^{a, b}$ Within days in the same treatment. $A, B, C$ Within treatments in the same period. Different superscript letters indicate significant difference. Kruskal-Wallis (among treatments) and Mann-Whitney (between days of culture) tests were used.

greater $(P<0.05)$ oocyte diameter than the other treatments, except when compared to AN2000 treatment.

\section{ROS levels after culture}

The levels of ROS in the culture medium at days 1 and 7 are shown in Table 4. At day 1 of culture, anethole at 30 and $2000 \mu \mathrm{g} / \mathrm{mL}$ reduced $(P<0.05)$ the ROS levels compared to the cultured control treatment. In addition, AN2000 treatment showed lower $(P<0.05)$ levels of ROS than AA treatment. However, at day 7 of culture, AN30 treatment showed the lowest $(P<0.05)$ level of ROS. Furthermore, ROS production increased $(\mathrm{P}<0.05)$ from day 1 to day 7 of culture in all treatments, except in the cultured control and AN30 treatments.

\section{Detection of cell proliferation by PCNA marker}

The percentage of labeling intensity for PCNA in preantral follicles in all treatments is shown in Table 5. A stronger
$(P<0.05)$ labeling intensity was found in granulosa cells of follicles in the AN30 treatment, compared to the noncultured control, cultured control, and AA treatments.

\section{Discussion}

The present study investigated for the first time the effect of anethole on the in vitro culture of caprine preantral follicles enclosed in ovarian tissue. In general, anethole improved follicle survival and growth after 7 days of culture in different concentrations.

Anethole at the highest tested concentration $(2000 \mu \mathrm{g} / \mathrm{mL})$ had a greater percentage of morphologically normal follicles compared to the other treatments after culture. Anethole acts mainly as an antioxidant, as previously shown in vivo $(25,26)$ and in vitro $(10,13)$. Specifically, anethole increases intracellular levels of glutathione peroxidase and inhibits lipid peroxidation. Glutathione peroxidase can react with $\mathrm{H}_{2} \mathrm{O}_{2}$ and with a great variety of lipid hydroperoxides, and is considered responsible for protecting the cell membrane against oxidative damage (27). Therefore, the above potential mechanism may have been responsible for the improvement in follicular morphology maintenance observed in the present study. The addition of anethole at lower concentrations reduced the percentage of normal follicles compared to the cultured control treatment only at day 1 of culture. The anethole acts like antioxidants, by inhibiting lipid-peroxidation as well as hydroxyl radical scavengers. However, Chainy et al. (13) demonstrated that anethole in a lower concentration presented pro-oxidant action, which could explain the transient effect of anethole on the reduction of normal follicles on day 1 of culture.

In vitro culture conditions have a profound influence on follicular activation, i.e., the transition from primordial to developing follicles. In the present study, the addition of anethole to the control medium did not improve follicular activation after 7 days of culture. The follicular activation observed in the cultured control treatment might have been induced by the suitable composition of the culture 
Table 5. Percentage of labeling intensity for PCNA in preantral follicles in non-cultured ovarian tissue and tissue cultured for 7 days in control medium with or without supplementation of $50 \mu \mathrm{g} / \mathrm{mL}$ of ascorbic acid (AA) or anethole at 30 (AN30), 300 (AN300) or $2000 \mu \mathrm{g} / \mathrm{mL}$ (AN2000).

\begin{tabular}{lccl}
\hline Treatments & Absent & Weak $(<50 \%)$ & Strong $(>50 \%)$ \\
\hline Non-cultured control & $41.2(14 / 34)$ & $35.3(12 / 34)$ & $23.5(8 / 34)$ \\
Cultured control & $31.6(27 / 76)^{\mathrm{A}}$ & $50.0(38 / 76)^{\mathrm{A}}$ & $18.4(14 / 76)^{\mathrm{A}}$ \\
AA & $32.2(28 / 87)^{\mathrm{A}}$ & $39.1(34 / 87)^{\mathrm{A}}$ & $28.7(25 / 87)^{\mathrm{AC}}$ \\
AN30 & $21.3(13 / 61)^{\mathrm{A}}$ & $32.7(20 / 61)^{\mathrm{A}}$ & $46.0(28 / 61)^{\star \mathrm{B}}$ \\
AN300 & $19.1(9 / 47)^{\star \mathrm{A}}$ & $44.7(21 / 47)^{\mathrm{A}}$ & $36.2(17 / 47)^{\mathrm{BC}}$ \\
AN2000 & $19.1(17 / 89)^{\star \mathrm{A}}$ & $38.2(34 / 89)^{\mathrm{A}}$ & $42.7(38 / 89)^{\mathrm{BC}}$ \\
\hline
\end{tabular}

${ }^{*} \mathrm{P}<0.05$ compared to non-cultured control group. ${ }^{A, B, C}$ Within columns. Different superscript letters indicate significant difference (chi-squared test).

medium used in this study, which is rich in nutrients, such as amino acids and carbohydrates (5). Previous reports in goats (28), cows (29), and baboons (30) have also not shown a medium-supplementation effect on in vitro primordial follicle activation.

Follicular and oocyte diameters after 7 days of in vitro culture were greater in the AN30 treatment than in the other treatments, except for the AN2000 treatment. It has previously been described that anethole stimulates granulosa cell proliferation, and consequently follicular growth, during in vitro culture of isolated goat secondary follicles (10). In addition, anethole has been involved in hepatic regeneration in mice (31). It has been shown that substances with antioxidant properties are directly related to a cascade of events that lead to growth and cell differentiation (32).

In the present study, ascorbic acid was used as an antioxidant positive control. The ascorbic acid addition did not reduce significantly ROS levels regardless the culture time. In general, antioxidant substances protect the cell from the ROS actions by different ways such as preventing, removing, and restoring these species (33). The essential action of the ascorbic acid is restoring the cell damages caused by ROS not necessarily by reducing ROS production. As a matter of fact, the results obtained in the present paper are in agreement with previous studies $(10,33)$ that have shown that the ROS levels were not affected by ascorbic acid addition. On the other hand, anethole at $30 \mu \mathrm{g} / \mathrm{mL}$ reduced the ROS level at the end of the culture period compared to the other treatments and, interestingly, improved follicular and oocyte growth rates. The assessment of ROS production has been an important tool to determine the presence of free radicals that may exert a

\section{References}

1. Pepling ME. From primordial germ cell to primordial follicle: mammalian female germ cell development. Genesis 2006; 44: 622-632, doi: 10.1002/dvg.20258.

2. Figueiredo JR, Rodrigues APR, Amorim CA, Silva JRV. Manipulação de oócitos inclusos em folículos ovarianos deleterious effect on cultured cells (34). In this sense, it has been demonstrated that an alteration of the optimal concentration of ROS initiates apoptosis, provoking damages in all follicular stages $(10,34)$. An appropriate antioxidant concentration in the culture medium reduces the cell membrane impairment (35) due to its importance in maintaining cellular homeostasis, as well as in modulating physiological events that enhance cell development (36).

PCNA staining has commonly been used to evaluate cell proliferation, and has served as a marker for in vitro follicular development in several species such as human (37), mice (38), and caprine (32). In the present study, anethole at a dose of $30 \mu \mathrm{g} / \mathrm{mL}$ more effectively stimulated granulosa cell proliferation; furthermore, it also promoted greater follicular diameter. The positive PCNA staining observed in the present study might have been a result of DNA repairing (39) during the intense RNA transcription that occurs as the oocyte grows (40).

In conclusion, supplementation of culture medium with anethole improves survival and early follicle development in the caprine species. However, these parameters are affected differently by the concentration of anethole.

\section{Acknowledgements}

This work was supported by the National Council for Scientific and Technological Development (CNPq) and Coordination for the Improvement of Higher Education Personnel (CAPES). N.A.R. Sá is a recipient of a grant from CAPES. The authors thank the laboratory colleagues for their help and Francisco L.N. de Aguiar for his technical assistance. pré-natais, In: Gonçalves PBD, Figueiredo JR, Freitas VJF (Editors). Biotécnicas aplicadas a reprodução animal. São Paulo: Roca; 2008. p 261-291.

3. Magalhães DM, Araujo VR, Verde IBL, Matos MHT, Silva $\mathrm{RC}$, Lucci CM, et al. Different follicle-stimulating hormone 
(FSH) sources influence caprine preantral follicle viability and development in vitro. Braz J Vet Res Anim Sci 2009; 46: 378-386, doi: 10.11606/issn.1678-4456.bjvras.2009.26787.

4. Fischer B, Bavister BD. Oxygen tension in the oviduct and uterus of rhesus monkeys, hamsters and rabbits. J Reprod Fertil 1993; 99: 673-679, doi: 10.1530/jrf.0.0990673.

5. Silva GM, Araújo VR, Duarte ABG, Chaves RN, Silva CMG, Lobo $\mathrm{CH}$, et al. Ascorbic acid improves the survival and in vitro growth of isolated caprine preantral follicles. Anim Reprod 2011; 8: 14-24.

6. Agarwal A, Aponte-Mellado A, Premkumar BJ, Shaman A, Gupta $S$. The effects of oxidative stress on female reproduction: a review. Reprod Biol Endocrinol 2012; 10: 49-56, doi: 10.1186/1477-7827-10-49.

7. Uhm SJ, Gupta MK, Yang JH, Lee SH, Lee HT. Selenium improves the developmental ability and reduces the apoptosis in porcine parthenotes. Mol Reprod Dev 2007; 74: 1386-1394, doi: 10.1002/mrd.20701.

8. Lima-Verde IB, Matos MHT, Bruno JB, Martins FS, Santos $R R$, Báo $S N$, et al. Effects of $\alpha$-tocopherol and ternatin antioxidants on morphology and activation of goat preantral follicles in vitro cultured. Arq Bras Med Vet Zootec 2009; 61: 57-65, doi: 10.1590/S0102-09352009000100009.

9. Gomes RG, Lisboa LA, Silva CB, Max MC, Marino PC, Oliveira RL, et al. Improvement of development of equine preantral follicles after 6 days of in vitro culture with ascorbic acid supplementation. Theriogenology 2015; 84: 750-755, doi: 10.1016/j.theriogenology.2015.05.006.

10. Sá NAR, Araújo VR, Correia HHV, Ferreira ACA, Guerreiro $\mathrm{DD}$, Sampaio AM, et al. Anethole improves the in vitro development of isolated caprine secondary follicles. Theriogenology 2017; 89: 226-234, doi: 10.1016/j.theriogenology.2015.12.014.

11. Yea SS, Jeong HS, Choi CY, Park KR, Oh S, Shin JG, et al. Inhibitory effect of anethole on T-lymphocyte proliferation and interleukin-2 production through down-regulation of the NF-AT and AP-1. Toxicol In Vitro 2006; 20: 1098-1105, doi: 10.1016/j.tiv.2006.01.020.

12. Polzin GM, Stanfill SB, Brown CR, Ashley DL, Watson CH. Determination of eugenol, anethole, and coumarin in the mainstream cigarette smoke of Indonesian clove cigarettes. Food Chem Toxicol 2007; 45: 1948-1953, doi: 10.1016/j.fct.2007. 04.012.

13. Chainy GB, Manna SK, Chaturvedi MM, Aggarwal BB. Anethole blocks both early and late cellular responses transduced by tumor necrosis factor: effect on NF-kB, AP-1, JNK, MAPKK and apoptosis. Oncogene 2000; 19: 2943-2950, doi: 10.1038/sj.onc.1203614.

14. Ghelardini C, Galeotti N, Mazzanti G. Local anaesthetic activity of monoterpenes and phenylpropanes of essential oils. Planta Med 2001; 67: 564-566, doi: 10.1055/s-200116475.

15. Duvoix A, Delhalle $S$, Blasius $R$, Schnekenburger $M$, Morceau $F$, Fougère $M$. et al. Effect of chemopreventive agents on glutathione S-transferase P1-1 gene expression mechanisms via activating protein 1 and nuclear factor kappaB inhibition. Biochem Pharmacol 2004; 68: 1101-1111, doi: 10.1016/ j.bcp.2004.05.032.

16. Magalhães-Padilha DM, Geisler-Lee J, Wischral A, Gastal $\mathrm{MO}$, Fonseca GR, Eloy YR, et al. Gene expression during early folliculogenesis in goats using microarray analysis. Biol Reprod 2013; 89: 19, 1-12.
17. Cadenas JM, Leiva-Revilla J, Vieira LA, Apolloni LB, Aguiar $\mathrm{FL}$, Alves BG, et al. Caprine ovarian follicle requirements differ between preantral and early antral stages after IVC in medium supplemented with GH and VEGF alone or in combination. Theriogenology 2017; 87: 321-332, doi: 10.1016/ j.theriogenology.2016.09.008.

18. Adams GP, Singh J, Baerwald AR. Large animal models for the study of ovarian follicular dynamics in women. Theriogenology 2012; 78: 1733-1748, doi: 10.1016/j.theriogeno logy.2012.04.010.

19. Chaves RN, Martins FS, Saraiva MV, Celestino JJ, Lopes $\mathrm{CA}$, Correia JC, et al. Chilling ovarian fragments during transportation improves viability and growth of goat preantral follicles cultured in vitro. Reprod Fertil 2008; 20: 640-647, doi: 10.1071/RD07195.

20. Rossetto R, Lima-Verde IB, Matos MH, Saraiva MV, Martins FS, Faustino LR, et al. Interaction between ascorbic acid and follicle-stimulating hormone maintains follicular viability after long-term in vitro culture of caprine preantral follicles. Domest Anim Endocrinol 2009; 37: 112-123, doi: 10.1016/ j.domaniend.2009.04.003.

21. Coelho-de-Souza NA, Lahlou S, Barreto JE, Yum ME, Oliveira AC, Oliveira HD, et al. Essential oil of Croton zehntneri and its major constituent anethole display gastroprotective effect by increasing the surface mucous layer. Fundam Clin Pharmacol 2013; 27: 288-298, doi: 10.1111/ j.1472-8206.2011.01021.x.

22. Silva JRV, Báo SN, Lucci CM, Carvalho FCA, Andrade ER, Ferreira MAL, et al. Morphological and ultrastructural changes occurring during degeneration of goat preantral follicles preserved in vitro. Anim Reprod Sci 2001; 66: 209-223, doi: 10.1016/S0378-4320(01)00102-6.

23. Sampaio da Silva AM, Bruno JB, Lima LF, Ribeiro de Sá NA, Lunardi FO, Ferreira AC, et al. Connexin 37 and 43 gene and protein expression and developmental competence of isolated ovine secondary follicles cultured in vitro after vitrification of ovarian tissue. Theriogenology 2016; 85: 1457-1467, doi: 10.1016/j.theriogenology.2016.01.001.

24. Loetchutinat S, Kothan S, Dechsupa J, Meesungnoen J, Jay-Gerin SM. Spectrofluorometric determination of intracellular levels of reactive oxygen species in drug-sensitive and drug-resistant cancer cells using the $2^{\prime}, 7^{\prime}$-dichlorofluorescein diacetate assay. Radiat Phys Chem 2005; 72: 323-331, doi: 10.1016/j.radphyschem.2004.06.011.

25. Leal-Cardoso JH, Fonteles MC. Pharmacological effects of essential oils plants of the Northeast of Brazil. An Acad Bras Cienc 1999; 71: 207-213.

26. Freire RS, Morais SM, Catunda-Junior FE, Pinheiro DC. Synthesis and antioxidant, anti-inflammatory and gastroprotector activities of anethole and related compounds. Bioorg Med Chem 2005; 13: 4353-4358, doi: 10.1016/j.bmc.2005.03.058.

27. Imai $\mathrm{H}$, Nakagawa $\mathrm{Y}$. Biological significance of phospholipid hydroperoxide glutathione peroxidase (PHGPx, GPx4) in mammalian cells. Free Radic Biol Med 2003; 34: 145-169, doi: 10.1016/S0891-5849(02)01197-8.

28. Martins FS, Celestino JJ, Saraiva MV, Chaves RN, Rossetto $\mathrm{R}$, Silva $\mathrm{CM}$, et al. Interaction between growth differentiation factor 9, insulin-like growth factor I and growth hormone on the in vitro development and survival of goat preantral follicles. Braz J Med Biol Res 2010; 43: 728-736, doi: 10.1590/S0100-879X2010007500066. 
29. Braw-Tal R, Yossefi S. Studies in vivo and in vitro on the initiation of follicle growth in the bovine ovary. $J$ Reprod Fertil 1997; 109: 165-171, doi: 10.1530/jrf.0.1090165.

30. Fortune JE, Kito S, Wandji SA, Srsen V. Activation of bovine and baboon primordial follicles in vitro. Theriogenology 1998; 49: 441-449, doi: 10.1016/S0093-691X(97) 00416-0.

31. Marshall $A D$, Caldwell J. Lack of influence of modulators of epoxide metabolism on the genotoxicity of trans-anethole in fresh isolated rat hepatocytes assessed with the unscheduled DNA synthesis assay. Food Chem Toxicol 1996; 34: 337-345, doi: 10.1016/0278-6915(96)00109-3.

32. Silva JRV, van den Hurk R, Costa SH, Andrade ER, Nunes AP, Ferreira FV, et al. Survival and growth of goat primordial follicles after in vitro culture of ovarian cortical slices in media containing coconut water. Anim Reprod Sci 2004; 81: 273-286, doi: 10.1016/j.anireprosci.2003.09.006.

33. Tagler D, Makanji Y, Tu T, Bernabé BP, Lee R, Zhu J. Promoting extracellular matrix remodeling via ascorbic acid enhances the survival of primary ovarian follicles encapsulated in alginate hydrogels. Biotechnol Bioeng 2014; 7: 1417-1429, doi: $10.1002 /$ bit.25181.
34. Behrman HR, Kodaman PH, Preston SL, Gao S. Oxidative stress and the ovary. J Soc Gynecol Investig 2001; 8: 40-42.

35. Alvarez CA, Moraes GV. Efeitos da selenometionina e vitamina C sobre o sêmen. SaBios: Rev Saúde Biol 2006; 1: 42-51.

36. Hovatta O, Silye R, Abir R, Krausz T, Winston RML. Extracellular matrix improves survival of both stored and fresh human primordial and primary ovarian follicles in longterm culture. Hum Reprod 1997; 12: 1032-1036, doi: 10.1093/ humrep/12.5.1032.

37. Oktay K, Karlikaya G, Akman O, Ojakian GK, Oktay M. Interaction of extracellularmatrix and Activin A in the initiation of follicle growth in the mouse ovary. Biol Reprod 2000; 63: 457-461, doi: 10.1095/biolreprod63.2.457.

38. Oktay K, Schenken RS, Nelson JF. Proliferating cell nuclear antigen marks the initiation of folicular growth in the rat. Biol Reprod 1995; 53: 295-301, doi: 10.1095/biolreprod53.2.295.

39. Downey KM, Tan CK, So AG. DNA polymerase delta: a second eucaryotic DNA replicase. Bioessays 1990; 12 : 231-236, doi: 10.1002/bies.950120507.

40. Lintern-Moore S, Moore GPM. The initiation of follicle and oocyte growth in the mouse ovary. Biol Reprod 1979; 20: 773-778, doi: 10.1095/biolreprod20.4.773. 